\title{
PENGARUH PANDEMI VIRUS CORONA DAN INFORMASI AKUNTANSI TERHADAP KELANGSUNGAN USAHA MIKRO, KECIL, DAN MENENGAH
}

\author{
Nia Pratiwi 1), Rahman Sastrawan ${ }^{2)}$, \& Chornolius Hendreo ${ }^{3)}$ \\ ${ }^{1}$ Jurusan Akuntansi Politeknik Negeri Pontianak \\ email: pratiwinia19@gmail.com \\ 2 Jurusan Akuntansi Politeknik Negeri Pontianak \\ email: namanyarahmansastrawan@gmail.com \\ ${ }^{3}$ Jurusan Akuntansi Politeknik Negeri Pontianak \\ email: chornoliushendreo@gmail.com
}

\begin{abstract}
The purpose of this study was to see the effect of the coronavirus pandemic and accounting information on business continuity. The method of this research is the level of clarity (explanatory) and this type of research is quantitative by conducting surveys and distributing questionnaires to MSME actors in Kapuas District. After the respondent fills out the questionnaire, the data will be processed and presented in the form of a Likert scale. Respondents in this study were SMEs in Kapuas District in Sanggau District. The results of this study show that the independent variables jointly affect business continuity (MSMEs), while partially the product selling price and cost of production have a significant effect on the business continuity variable (MSMEs). For the variables of the corona pandemic, financial reports, and effective planning do not affect business continuity. This study also shows that the influence of independent variables on business continuity (MSMEs) has a figure of $27.7 \%$, for the rest it has a figure of $72.3 \%$ caused by other factors.
\end{abstract}

Keywords: coronavirus pandemic, accounting information, business continuity.

\section{PENDAHULUAN}

Munculnya virus corona (Covid-19) pertama kali diberitakan dari Negara Tiongkok di Provinsi Hubei, Kota Wuhan. Pada akhir tahun 2019 Pemerintah Tiongkok menyatakan bahwa, penderita virus corona pertama kali berusia 55 tahun adalah masyarakat Hubei. Pada bulan Desember 2019 tercatat sebanyak 27 orang penderita virus corona di Provinsi Hubei (Saputra, 2020). Pada tanggal 2 Maret 2020, Presiden Joko Widodo menyampaikan bahwa adanya masyarakat di Indonesia yang terinfeksi virus corona. Pasien terinfeksi pertama kali di Indonesia berawal dari perempuan berusia 31 tahun yang berada di sebuah restoran di Jakarta.
Virus corona masuk ke Indonesia melalui warga negara Jepang yang melakukan kunjungan wisata ke tanah air. Pada tanggal 11 Maret 2020, Tedros Adhanom Ghebresyesus perwakilan organisasi kesehatan dunia atau biasa dikenal dengan World Health Organization (WHO) mengumumkan kepada seluruh dunia bahwa virus corona merupakan wabah atau pandemi (Hakim, 2020).

Organisasi kesehatan dunia menyatakan bahwa wabah corona bisa dicegah dengan melakukan prosedur kesehatan, yaitu lingkungan yang bersih meliputi: cuci tangan lebih sering menggunakan sabun atau hand sanitizer, menutup hidung dan mulut dengan masker, jaga jarak atau interaksi fisik, dan 
diam di rumah saja untuk menghindari virus corona. Pandemi corona juga akan memberikan dampak pada perekonomian di Indonesia secara keseluruhan, yaitu menurunnya pendapatan bagi perusahaan besar dan perusahaan kecil. Perusahaan kecil biasa juga disebut dengan usaha mikro, kecil, dan menengah (UMKM), sedangkan kontribusi terbesar untuk kekuatan ekonomi nasional adalah berasal dari UMKM. Produk-produk yang dihasilkan dari pelaku UMKM sangat bervariasi, sehingga dengan adanya pandemi corona membuat pelaku UMKM sulit untuk memasarkan produk-produk yang dihasilkannya, baik di luar negeri maupun dalam negeri.

Sanggau merupakan kabupaten yang berada di Kalimantan Barat dan berbatasan dengan negara Malaysia, selain itu Kabupaten Sanggau juga tidak luput dari dampak pandemi corona. Sebelum terjadinya wabah corona, pertumbuhan UMKM di Kabupaten Sanggau khususnya usaha kuliner sangat berkembang. Perkembangan tersebut dapat dilihat dari jumlah usaha yang dijalankan oleh pelaku UMKM. Pelaku UMKM tahun 2019 berjumlah 5.624 unit dan pada tahun 2020 berjumlah 4.825 unit usaha. Penurunan unit usaha sebesar 14\% diakibatkan terjadinya wabah corona, sehingga berdampak pada kelangsungan UMKM.

Informasi akuntansi sangat penting bagi pelaku usaha dalam mengembangkan bisnisnya. Menurut Nurwani dan Safitri (2019) menyebutkan bahwa ada pengaruh antara penggunaan informasi akuntansi terhadap keberhasilan usaha secara signifikan, informasi akuntansi meliputi : informasi laporan keuangan, perencanaan efektif, informasi harga pokok produksi, dan informasi penentuan harga jual.

\section{KAJIAN LITERATUR DAN PEGEMBANGAN HIPOTESIS}

Menurut Ediraras (2010) menyatakan bahwa keberhasilan suatu usaha dipengaruhi oleh infromasi akuntansi. Infomasi akuntansi sangat berguna dalam mengambil suatu keputusan, sehingga bisa memprediksi pertumbuhan usaha. Informasi yang digunakan bisa saja berupa informasi kualitatif maupun kuantitatif, sehingga memudahkan pelaku UMKM dalam pengambilan keputusan untuk menjalankan bisnisnya. Informasi akuntansi yang dibutuh pelaku UMKM untuk mempengaruhi keberhasilan bisnisnya adalah yaitu; laporan keuangan, perencanaan efektif, harga pokok produksi, dan harga jual produk. PSAK Nomor 1 (2015) laporan keuangan adalah penyajian keuangan yang berkaitan pada kinerja perusahaan. Tujuan dari laporan keuangan adalah memberikan atau menyajikan informasi tentang kinerja keuangan yang meliputi: laporan neraca, laba rugi, perubahan atas modal, arus kas dan CALK yang bermanfaat bagi pengguna laporan yaitu pelaku UMKM di Kabupaten Sanggau, agar mudah dalam pengambilan keputusan.

Fungsi dari salah satu manajemen yang utama adalah perencanaan. Perencanaan secara garis besar merupakan suatu proses penentuan tujuan perusahaan. Menurut Hidayat \& Pesudo (2019) menyatakan bahwa perencanaan bisa mempengaruhi suatu nilai usaha. Harga pokok produksi diukur dengan menghitung berapa biaya yang telah dikeluarkan selama produksi, sehingga laba yang diperoleh sesuai dengan tujuan pelaku UMKM. Mulyadi (2014) menyebutkan bahwa harga pokok produksi adalah pengeluaran biaya untuk memperoleh barang dan jasa selama periode tertentu. Harga jual produk adalah jumlah uang yang dinaikkan untuk mendapatkan keuntungan dari jumlah 
barang yang dijual. Ediraras (2010) informasi akuntansi sangat penting dalam menentukan harga jual produk. Pelaku UMKM harus mempertimbangkan indikator-indikator yang mempengaruhi harga jual produk, sehingga produk yang dipasarkan bisa terjual dengan baik. Kelangsungan usaha (going concern) adalah kegiatan hidup suatu usaha yang menjalankan operasinya secara terus menerus. Menurut Standar Profesional Akuntan Publik (2016) menyatakan bahwa going concern adalah kelangsungan hidup suatu usaha, pelaku UMKM mampu bertahan dalam menjalankan bisnisnya dengan jangka waktu yang cukup lama. Wibowo \& Kurniawati (2016) menyatakan bahwa keberhasilan suatu usaha dapat dilihat dari peningkatan pendapatan penjualan, pendapatan penjualan berupa, banyaknya order, promosi pesanan, harga yang ditawarkan dan hasil penjualan. Kerangka penelitian ini dapat dilihat pada gambar 1 .

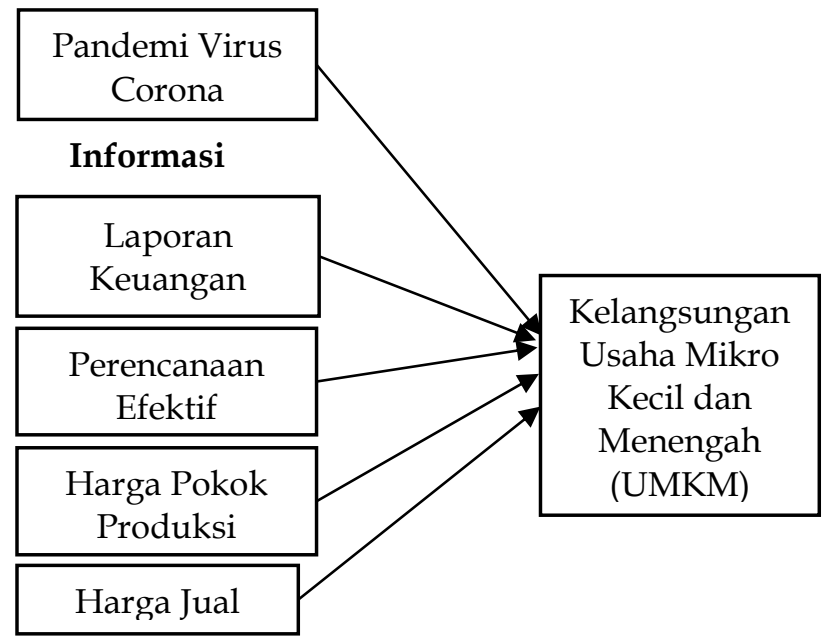

\section{Gambar 1. Kerangka Penelitian}

Pada situasi saat ini kita dapat melihat pertumbuhan perekonomian di seluruh dunia mengalami penurunan, begitu juga pertumbuhan perekonomian di Indonesia. Penurunan pertumbuhan perekonomian di Indonesia bisa saja diakibatkan oleh pandemi virus corona, dengan turunnya pertumbuhan ekonomi otomatis pendapatan UMKM di Kecamatan Kapuas, Kabupaten Sanggau menurun. Pandemi virus corona berpotensi mematikan sektor perekonomian di seluruh daerah khususnya pelaku UMKM di Kecamatan Kapuas, Kabupaten Sanggau. Dengan demikian, dapat dikemukakan hipotesis pertama adalah. $\mathrm{H}_{1}$ : Pandemi virus corona berpengaruh terhadap kelangsungan UMKM di Kecamatan Kapuas, Kabupaten Sanggau.

Laporan keuangan merupakan alat untuk mengukur kinerja keuangan, dengan melihat berapa besar pendapatan yang diperoleh, sehingga pelaku UMKM bisa mengambil sebuah keputusan akurat dan tepat. Harap (2010) menyatakan bahwa laporan keuangan sangat penting dalam menilai kinerja perusahaan atau usaha, sehingga permasalahan yang ada dalam keuangan dapat terdeteksi. Menurut Hanum (2013) menyatakan bahwa pandangan pimpinan perusahaan kecil pada informasi akuntansi keuangan dapat mempengaruhi kemajuan perusahaan kecil. Dengan demikian, dapat dikemukakan hipotesis kedua adalah.

$\mathrm{H}_{2}$ : Laporan keuangan berpengaruh positif terhadap kelangsungan UMKM di Kecamatan Kapuas, Kabupaten Sanggau.

Strategi bisnis sangat penting dilakukan, agar kelangsungan usaha tetap beroperasi terus menerus. Menurut Suci (2012) menyatakan bahwa strategi bisnis sangat diperlukan oleh suatu perusahaan, karena strategis bisnis dan orientasi kewirausahaan akan meningkat kinerja perusahaan. Menurut Sutrisno et al (2016) menyatakan bahwa perencanaan yang efektif dapat menetukan arah perusahaan yang jelas, jika menggunakan pendekatan perencanaan prosedural dan subsantif. Dengan demikian, dapat dikemukakan hipotesis ketiga adalah. 
$\mathrm{H}_{3}$ : Perencanaan efektif berpengaruh positif terhadap kelangsungan UMKM di Kecamatan Kapuas, Kabupaten Sanggau.

Menurut Purnamawati et al., (2018) menyatakan bahwa harga pokok produksi yang dihitung dengan metode full costing akan mengakibatkan biaya sedikit lebih tinggi dari pada metode perusahaan. Penentuan harga pokok produksi merupakan hal yang sangat penting dalam menentukan laba usaha. Penelitian Nugroho (2017) menyatakan bahwa harga pokok produksi yang dihitung perusahaan masih menggunakan metode sendiri.

Menurut Waryanto \& Nasrulloh (2014) menyatakan harga pokok produksi dapat mempengaruhi harga jual, sehingga akan dapat meningkatkan laba. Dengan demikian, dapat dikemukakan hipotesis keempat adalah.

H4 : Harga pokok produksi berpengaruh positif terhadap kelangsungan UMKM di Kecamatan Kapuas, Kabupaten Sanggau.

Penentuan harga jual produk sangat penting dalam menentukan laba rugi, apabila penentuan harga jual produk tidak tepat, maka perusahaan bisa saja mengalami kerugian. Menurut Wibowo \& Kurniawati (2016) menyatakan bahwa harga jual produk mempengaruhi keberhasilan perusahaan. Penelitian yang dilakukan Wibowo \& Kurniawati (2016) menyatakan bahwa harga jual berpengaruh terhadap keberhasilan UMKM. Dengan demikian, dapat dikemukakan hipotesis kelima adalah.

H5 : Harga jual produk berpengaruh positif terhadap kelangsungan UMKM di Kabupaten Sanggau, Kecamatan Kapuas.

\section{METODE PENELITIAN}

Penelitian ini berbentuk kuantitatif yang menjelaskan relasi antara variabel satu dengan vairabel lainnya dengan tingkat penjelas. Data yang digunakan pada penelitian ini adalah data primer, kemudian data disebar berbentuk kuesioner ke reponden. Responden penelitian ini adalah pelaku UMKM Kecamatan Kapuas, Kabupaten Sanggau. Populasi yang digunakan sebanyak 100 pelaku UMKM dengan teknik pemilihan sampel purposive sampling.

Variabel independen (X) yang digunakan adalah (X1) pandemi virus corona, (X2) laporan keuangan, (X3) perencanaan efektif, (X4) harga pokok produksi, dan (X5) harga jual produk, sedangkan variabel dependen (Y) kelangsungan usaha. Variabel dependen dan independen diukur dengan menggunakan skala likert dalam bentuk kuesioner. Pertanyaan dalam kuesioner terdiri dari, Sangat Tidak Setuju (STS) mempunyai nilai 1, Tidak Setuju (TS) mempunyai nilai 2, Netral (N) mempunyai nilai 3, Setuju (S) mempunyai nilai 4, dan Sangat Setuju (SS) mempunyai nilai 5.

Pengujian data pada penelitian ini menggunakan uji kualitas data dan asumsi klasik, sedangkan untuk uji hipotesis menggunakan model regresi dengan aplikasi SPPS versi 25. Pada uji hipotesis memiliki persamaan regresi linear berganda di bawah ini:

$$
Y=\alpha+\beta_{1} . X_{1}+\beta_{2} . X_{2}+\beta_{3} . X_{3}+\beta_{4} X_{4}+
$$

$\beta_{5} X_{5}+\epsilon$

Diketahui:

$\mathrm{Y}=$ kelangsungan usaha

$\alpha=$ konstanta

$\beta_{1}, \beta_{2}, \beta_{3}, \beta_{4}, \beta_{5}=$ koefisien regresi

$\mathrm{X}_{1}=$ pandemi corona

$\mathrm{X}_{2}=$ laporan keungangan

$\mathrm{X}_{3}=$ perencanaan efektif

$\mathrm{X}_{4}=$ harga pokok produksi

$\mathrm{X}_{5}=$ harga jual produk

$\epsilon=$ nilai residu

\section{HASIL}

Uji stastistik deskriptif dilakukan untuk melihat bentuk data repsonden yang digunakan. Hasil analisis uji statistik 
deskriptif dalam penelitian ini disajikan pada Tabel 1 berikut ini.

Tabel 1. Hasil Uji Statistik Deskriptif

\begin{tabular}{lccccc}
\hline \multicolumn{1}{c}{ Variabel } & N & Min & Max & Mean & $\begin{array}{c}\text { Std. } \\
\text { Deviation }\end{array}$ \\
\hline $\begin{array}{l}\text { Pandemi } \\
\begin{array}{l}\text { Corona } \\
\text { Laporan }\end{array}\end{array}$ & 100 & 12,00 & 20,00 & 17,8900 & 1,90637 \\
$\begin{array}{l}\text { Keuangan } \\
\begin{array}{l}\text { Perencanaan } \\
\text { Efektif }\end{array}\end{array}$ & 100 & 15,00 & 25,00 & 17,0100 & 2,92152 \\
$\begin{array}{l}\text { Harga Pokok } \\
\text { Penjualan }\end{array}$ & 100 & 12,00 & 20,00 & 15,9400 & 2,42387 \\
$\begin{array}{l}\text { Harga Jual } \\
\text { Produk }\end{array}$ & 100 & 13,00 & 20,00 & 14,8500 & 1,95595 \\
$\begin{array}{l}\text { Kelangsungan } \\
\text { Usaha }\end{array}$ & 100 & 8,00 & 20,00 & 14,5900 & 2,39568 \\
\hline
\end{tabular}

Sumber: Data Diolah, 2020

Pada Tabel 1 memperlihatkan bahwa variabel pandemi virus corona (X1) memiliki 100 responden dengan nilai minimal sebesar 12 , nilai maksimal 20 , dan nilai mean sebesar $17,8900>$ nilai standar deviasi 1,90637. Hal ini membuktikan bahwa setiap pertanyaan pada variabel pandemi virus corona dapat menjelaskan sebaran data.

Pada Tabel 1 memperlihatkan bahwa variabel laporan keuangan (X2) memiliki 100 responden dengan nilai minimal sebesar 15 , nilai maksimal 25 , dan nilai mean sebesar 17,0100 > nilai standar deviasi 2,92152. Hal ini membuktikan bahwa setiap pertanyaan pada variabel laporan keuangan dapat menjelaskan sebaran data.

Pada Tabel 1 memperlihatkan bahwa variabel perencanaan efektif (X3) memiliki 100 responden dengan nili minimal sebesar 12, nilai maksimal 20, dan nilai mean sebesar $15,9800>$ nilai standar deviasi 2,21556. Hal ini membuktikan bahwa setiap pertanyaan pada variabel perencanaan efektif dapat menjelaskan sebaran data.

Pada Tabel 1 memperlihatkan bahwa variabel harga pokok produksi (X4) memiliki 100 responden dengan nilai minimal sebesar 12, nilai maksimal 20, dan nilai mean sebesar $15,9400>$ nilai standar deviasi 2,42387. Hal ini membuktikan bahwa setiap pertanyaan pada variabel harga pokok produksi dapat menjelaskan sebaran data.

Pada Tabel 1 memperlihatkan bahwa variabel harga jual produk (X5) memiliki 100 responden dengan nilai minimal sebesar 13, nilai maksimal 20, dan nilai mean sebesar $14,8500>$ nilai standar deviasi 1,95595. Hal ini membuktikan bahwa setiap petanyaan pada variabel harga jual pdoduk dapat menjelaskan sebaran data.

Pada Tabel 1 memperlihatkan bahwa variabel kelangsungan usaha $(\mathrm{Y})$ memiliki 100 responden dengan nilai minimal sebesr 8 , nilai maksimal 20 , dan nilai mean sebesar $14,5900>$ nilai standar deviasi 2,39568. Hal ini membuktikan bahwa setiap pertanyaan pada variabel kelangsungan usaha dapat menjelaskan sebaran data.

\section{Tabel 2. Hasil Uji Kualitas Data}

\begin{tabular}{|c|c|c|c|c|c|c|}
\hline \multirow[b]{2}{*}{ Variabel } & \multicolumn{5}{|c|}{ Validitas } & $\begin{array}{l}\text { Reliabi- } \\
\text { litas }\end{array}$ \\
\hline & \multicolumn{5}{|c|}{ Korelasi Tiap-Tiap Item Pertanyaan } & $\begin{array}{l}\text { Cronsb- } \\
\text { ach's A }\end{array}$ \\
\hline $\begin{array}{l}\text { Pandemi } \\
\text { Corona (X1) }\end{array}$ & 0,664 & 0,773 & 0,774 & 0,775 & - & 0,729 \\
\hline $\begin{array}{l}\text { Laporan } \\
\text { Keuangan } \\
(\mathrm{X} 2)\end{array}$ & 0,817 & 0,888 & 0,867 & 0,861 & 0,877 & 0,914 \\
\hline $\begin{array}{l}\text { Perencanaan } \\
\text { Efektif (X3) }\end{array}$ & 0,664 & 0,822 & 0,841 & 0,747 & - & 0,774 \\
\hline $\begin{array}{l}\text { Harga Pokok } \\
\text { Produksi (X4) }\end{array}$ & 0,803 & 0,808 & 0,820 & 0,775 & - & 0,815 \\
\hline $\begin{array}{l}\text { Harga Jual } \\
\text { Produk (X5) }\end{array}$ & 0,643 & 0,694 & 0,896 & 0,872 & - & 0,794 \\
\hline $\begin{array}{l}\text { Kelangsungan } \\
\text { Usaha (Y) }\end{array}$ & 0,771 & 0,764 & 0,852 & 0,811 & - & 0,793 \\
\hline
\end{tabular}

Sumber: Data Diolah, 2020

Uji validitas data pada beberapa pertanyaan dikatakan valid atau layak jika $\mathrm{R}_{\text {hitung }}$ lebih besar dari $\mathrm{R}_{\text {tabel }}, \mathrm{R}_{\text {tabel }}$ untuk $\mathrm{df}=(\mathrm{N}-2)$ tingkat signifikan 0,01 sebesar 0,256 . Pada Tabel 2 memperlihatkan bahwa uji validitas variabel independen dan dependen dari beberapa pertanyaan mempunyai nilai $R_{\text {hitung }}>R_{\text {tabel. }}$. Dengan 
demikian, dapat dikatakan bahwa setiap pertanyaan dikatakan layak atau valid.

Uji reliabilitas bertujuan untuk melihat angka Cronbachs's Alpha, apabila angka Cronbach's Alpha pada beberapa variabel $>0,70$, maka tiap-tiap pertanyaan tersebut dikatakan reliabel (Ghozali, 2016). Pada Tabel 2 memperlilhatkan bahwa variabel independen dan dependen mempunyai angka Cronbach's Alpha > 0,07. Dengan demikian, dapat dikatakan bahwa keseluruhan item pertanyaan reliabel

Tabel 3. Hasil Uji Asumsi Klasik

\begin{tabular}{|c|c|c|c|c|}
\hline \multirow[b]{2}{*}{ Keterangan } & $\begin{array}{c}\text { Norm- } \\
\text { alitas }\end{array}$ & \multicolumn{2}{|c|}{ Multikolineritas } & \multirow[t]{2}{*}{ Sig } \\
\hline & $\begin{array}{l}\text { Asymp } \\
\text {. Sig } \\
(2- \\
\text { tailed })\end{array}$ & $\begin{array}{c}\text { Tolera } \\
\text {-nce }\end{array}$ & VIF & \\
\hline $\begin{array}{l}\text { Unstandardi- } \\
\text { zed Residual }\end{array}$ & 0,085 & & & \\
\hline $\begin{array}{l}\text { Pandemi } \\
\text { Corona (X1) }\end{array}$ & & 0,965 & 1,037 & 0,277 \\
\hline $\begin{array}{l}\text { Laporan } \\
\text { Keuangan } \\
(\mathrm{X} 2)\end{array}$ & & 0,797 & 1,255 & 0,712 \\
\hline $\begin{array}{l}\text { Perencanaan } \\
\text { Efektif (X3) }\end{array}$ & & 0,713 & 1,402 & 0,323 \\
\hline $\begin{array}{l}\text { Harga Pokok } \\
\text { Produksi (X4) }\end{array}$ & & 0,648 & 1,544 & 0,314 \\
\hline $\begin{array}{l}\text { Harga Jual } \\
\text { Produk (X5) }\end{array}$ & & 0,727 & 1,375 & 0,366 \\
\hline
\end{tabular}

Sumber: Data Diolah, 2020

Uji normalitas dilakukan untuk menguji variabel dependen dan variabel independen, apakah semua data berdistribusi normal atau tidak. Uji normalitas dilakukan dengan menggunakan uji Kolmogorov-Smirnov (K-S). Angka Asymp. Sig (2-tailed) pada Tabel 3 sebesar 0,085>0,05. Hal ini membuktikan bahwa semua data berdistribusi nomal.
Uji multikolinieritas dilakukan untuk menguji model regresi kedua variabel, yaitu variabel dependen dan independen. Uji multikolinieritas dibuktikan dengan melihat angka VIF dan angka tolerance. Apabila angka VIF < 10 dan angka tolerance $>0,10$ maka tidak terjadi gejala multikolinieritas (Ghozali, 2016). Angka tolerance variabel pandemi corona pada Tabel 3 sebesar 0,965, laporan keuangan sebesar 0,797, perencanaan efektif sebesar 0,713, harga pokok produksi sebesar 0,648, dan harga jual produk sebesar 0,727 , sedangkan nilai VIF variabel pandemi corona sebesar 1,037, laporan keuangan sebesar 1,255, perencanaan efektif sebesar 1,402, harga pokok produksi sebesar 1,544, dan harga jual produk sebesar 1,375. Dengan demikian, dapat dikatakan semua variabel angka tolerance $>0,10$ dan angka VIF $<10$, dapat dikatakan tidak ada gejala multikolinieritas.

Uji heteroskedastisitas dilakukan melalui uji glesjer, apabila probabilitas signifikansi dari macam-macam variabel independen $>0,05$, sehingga dapat dikatakan tidak terjadi heteroskedastisitas pada model regresi (Ghozali, 2016). Angka signifikansi pada Tabel 3 memperlihatkan bahwa variabel pandemi corona sebesar 0,277 , laporan keuangan sebesar 0,712, perencanaan efektif sebesar 0,323 , harga pokok produksi sebesar 0,314 , dan harga jual produk sebesar 0,366 . Hal ini membuktikan tidak terjadi heteroskedastisitas.

Tabel 4. Hasil Analisis Regresi

\begin{tabular}{lllll}
\hline \multirow{2}{*}{ Model } & \multicolumn{3}{c}{ Parsial (t) } & Hasil Hipotesis \\
\cline { 2 - 4 } & \multicolumn{1}{c}{$\mathrm{B}$} & \multicolumn{1}{c}{ t-hitung } & \multicolumn{1}{c}{ Sig } \\
\hline (Constant) & 9,480 & 2,843 & 0,005 & - \\
Pandemi Corona (X1) & 0,095 & 0,845 & 0,400 & H1. Ditolak \\
Laporan Keuangan (X2) & $-0,111$ & $-1,379$ & 0,171 & H2. Ditolak \\
Perencanaan Efektif (X3) & 0,188 & 1,672 & 0,098 & H3. Ditolak \\
Harga Pokok Produksi (X4) & 0,436 & 4,52 & 0,000 & H4. Diterima \\
Harga Jual Produk (X5) & $-0,313$ & $-2,488$ & 0,015 & H5. Diterima \\
\hline
\end{tabular}




\begin{tabular}{ll}
\hline Koefisien Determinasi (R Square) & $=0,277$ \\
Anova $(\mathrm{F})$ & $=7,214$ \\
Signifikansi F & $=0,000$ \\
\hline
\end{tabular}

Sumber: Data Diolah, 2020

Hasil analisis regresi pada Tabel 4 memperlihatkan nilai uji koefisien determinasi R Square sebesar 0,277, berarti variabel independen sama dengan $27,7 \%$. Nilai R Square sebesar $27,7 \%$ menunjukkan bahwa pengaruh variabel pandemi corona, laporan keuangan, perencanaan efektif, harga pokok produksi, dan harga jual produk terhadap kelangsungan usaha (UMKM) mempunyai hubungan yang lemah atau tidak kuat, sedangkan 72,3\% dipengaruhi lain di luar model.

Hasil analisis regresi pada Tabel 4 memperlihatkan nilai bahwa nilai $F_{\text {hitung }}$ $7,214>F_{\text {tabel }} 2,31$ dan nilai signifikansi $0,000<0,05$. Dengan demikian, variabel pandemi corona, laporan keuangan, perencanaan efektif, harga pokok produksi, dan harga jual produk terhadap kelangsungan usaha (UMKM) berpengaruh secara simultan.

Hasil analisis regresi pada Tabel 4 memperlihatkan bahwa persamaan regresi linear berganda sebagai berikut:

$$
\mathrm{Y}=9,480+0,095 \mathrm{X}_{1}-0,111 \mathrm{X}_{2}+
$$
$0,188 \mathrm{X}_{3}+0,436 \mathrm{X}_{4}-0,313 \mathrm{X}_{5}+\mathrm{e}$

Angka konstanta $(\alpha)$ 9,480 memiliki makna bahwa variabel pandemi corona, laporan keuangan, perencanaan efektif, harga pokok produksi, dan harga jual produk memiliki nilai nol (0), maka nilai variabel kelangsungan usaha sebesar 9,480. Angka koefisien regresi variabel pandemi corona sebesar 0,095 memiliki makna apabila pandemi corona mengalami kenaikan satu (1) satuan, maka terjadi peningkatan kelangsungan usaha sebesar 0,095, jika diasumsikan variabel lainya memiliki nilai nol.

Angka koefisien regresi variabel laporan keuangan sebesar -0,111 memiliki makna apabila laporan keuangan mengalami kenaikan satu (1) satuan, maka terjadi penurunan kelangsungan usaha sebesar 0,111 , jika diasumsikan variabel lainya memiliki nilai nol. Angka koefisien regresi variabel perencanaan efektif sebesar 0,188 memiliki makna apabila perencanaan efektif mengalami kenaikan satu (1) satuan, maka terjadi peningkatan kelangsungan usaha sebesar 0,188 , jika diasumsikan variabel lainnya memiliki nilai nol.

Angka koefisien regresi variabel harga pokok produksi sebesar 0,436 memiliki makna apabila harga pokok produksi mengalami kenaikan satu (1) satuan, maka terjadi peningkatan kelangsungan usaha sebesar 0,436, jika diasumsikan variabel lainnya memiliki nilai nol. Angka koefisien regresi variabel harga jual produk sebesar -0,313 memiliki makna apabila harga jual produk mengalami kenaikan satu (1) satuan, maka terjadi penurunan kelangsungan usaha sebesar 0,313 , jika diasumsikan variabel lainya memiliki nilai nol.

\section{PEMBAHASAN}

Hipotesis pertama (H1) memperlihatkan bahwa variabel pandemi virus corona tidak berpengaruh terhadap kelangsungan usaha (UMKM). Hasil pengujian ini dibuktikan dengan melihat nilai signifikan $0,400>0,05$ pada variabel pandemi virus corona, dan nilai thitung $0,845<$ nilai tabel 1,986 , sehingga dapat dikatakan hipotesis pertama ditolak. Tidak adanya pengaruh variabel pandemi virus corona terhadap variabel kelangsungan usaha (UMKM) disebabkan bahwa pelaku UMKM terus menerus melakukan kegiatan usaha walaupun keadaan pandemi virus corona. 
Hipotesis kedua (H2) memperlihatkan bahwa variabel laporan keuangan tidak berpengaruh atau berpengaruh lemah terhadap kelangsungan usaha (UMKM). Hasil pengujian ini dibuktikan dengan melihat nilai signifikan $0,171>0,05$ pada variabel laporan keuangan dan nilai thitung $1,379<$ nilai $t_{\text {tabel }} 1,986$, sehingga dikatakan hipotesis kedua ditolak. Tidak adanya pengaruh variabel laporan keuangan terhadap kelangsungan usaha (UMKM) disebabkan oleh laporan keuangan yang dibuat pelaku UMKM tidak sesuai dengan Standar Akuntansi keuangan UMKM (SAK EMKM), sehingga laporan keuangan tidak berpengaruh pada kelangsungan usaha (UMKM).

Hipotesis ketiga (H3) memperlihatkan bahwa variabel perencanaan efektif juga tidak berpengaruh positif tehadap kelangsungan usaha (UMKM). Hasil pengujian ini dibuktikan dengan melihat nilai signifikan $0,098>0,05$ pada variabel perencanaan efektif dan nilai thitung $1,672<$ nilai $t_{\text {tabel }} 1,986$, sehingga dikatakan hipotesis ketiga ditolak.

Tidak adanya pengaruh variabel perencanaan efektif terhadap kelangsungan usaha (UMKM) disebabkan pelaku UMKM tidak memikirkan ke depan rencana yang dijalankan dalam melakukan kegiatan usaha, sehingga perencanaan efektif tidak berpengaruh terhadap kelangsungan usaha (UMKM).

Hipotesis keempat (H4) menunjukkan bahwa variabel harga pokok produksi berpengaruh positif terhadap kelangsungan usaha (UMKM). Hasil pengujian ini dibuktikan dengan melihat nilai signifikansi $0,000<0,05$ pada variabel harga pokok produksi dan nilai $t_{\text {hitung }} 4,052>$ nilai tabe1 1,986 , sehingga dapat dikatakan hipotesis keempat diterima. Berpengaruhnya variabel harga pokok produksi terkait biaya yang dikeluarkan selama proses produksi. Biaya produksi diminimalkan sehingga berdampak pada keuntungan, keuntungan yang didapat memberikan kelangsungan usaha pada pelaku UMKM.

$$
\text { Hipotesis kelima }
$$

memperlihatkan bahwa variabel harga jual produk berpengaruh positif terhadap kelangsungan usaha (UMKM). Hasil pengujian ini dibuktikan dengan melihat nilai signifikansi $0,015<0,05$ pada variabel harga pokok produksi dan nilai thitung $2,488>$ nilai tabel 1,986 , sehingga hipotesis kelima diterima. Berpengaruhnya harga jual produk disebabkan produk yang dijual sesuai dengan keuangan konsumen miliki, selain itu harga jual produk dapat menentukan perputaran penjualan. Penjualan meningkat berdampak pada laba usaha, sehingga kelangsungan usaha (UMKM) berjalan dengan baik.

\section{SIMPULAN}

Tujuan dari penelitian ini adalah untuk menguji variabel pandemi virus corona, laporan keuangan, perencanaan efektif, harga pokok produksi, dan harga jual produk terhadap variabel kelangsungan usaha (UMKM).

Simpulan pertama, pandemi virus corona tidak berpengaruh secara signifikan terhadap kelangsungan usaha (UMKM). Kedua, laporan keuangan tidak berpengaruh secara signifikan terhadap kelangsungan usaha (UMKM). Ketiga, perencanaan efektif tidak berpengaruh secara signifikan terhadap kelangsungan usaha (UMKM). Keempat, harga pokok produksi berpengaruh secara signifikan terhadap kelangsungan usaha (UMKM). Kelima, harga jual produk berpengaruh secara signifikan terhadap kelangsungan usaha (UMKM).

Saran untuk penelitian selanjutnya adalah harus memperhatikan perluasan responden dan penambahan variabel, sehingga kelangsungan usaha (UMKM) menjadi lebih baik pada masa pandemi 
maupun new normal. Pemerintah juga harus lebih aktif memberikan pelatihan tentang menghitung dan menyusun laporan keuangan terhadap pelaku UMKM.

\section{REFERENSI}

ediraras, D. (2010). Akuntansi Dan Kinerja Ukm. Jurnal Ilmiah Ekonomi Bisnis. Https://Doi.Org/10.35760/Eb.

Ghozali, I. (2016). Aplikasi Analisis Multivariate Dengan Program IBM SPSS 23 . Edisi 8. Cetakan Ke-8. Semarang: Badan Penerbit Universitas Diponegoro. 2011.

HAKIM, R. N. (2020). Pengumuman Mendadak Jokowi Yang Kejutkan Pasien Positif Corona. Kompas. Https://Nasional.Kompas.Com/Read/ 2020/03/04/08051361/PengumumanMendadak-Jokowi-Yang-KejutkanPasien-Positif-Corona?Page=All

Hanum, Z. (2013). Pengaruh Persepsi Pengusaha KECIL Atas Informasi Akuntansi Keuangan Terhadap Keberhasilan Perusahaan (Survei Pada Usaha-Usaha Kecil Di Kota Medan). Accaunting Jurnal.

Harahap. (2010). Analisis Kritis Laporan Atas Laporan Keuangan. Analasis Laporan Keuangan.

Hidayat, S. W., \& Pesudo, D. A. A. (2019). Pengaruh Perencanaan Pajak Dan Kepemilikan Manajerial Terhadap Nilai Perusahaan Dengan Transparansi Perusahaan Sebagai Variabel Moderasi. International Journal Of Social Science And Business.

Https://Doi.Org/10.23887/Ijssb.V3i4. 21323

Maulana Saputra. (2020). Virus Corona Diduga Muncul Pertama Kali Pada 17 November 2019 Di Hubei. Kumparan.

Https://Kumparan.Com/Kumparanne ws/Virus-Corona-Diduga-Muncul-
Pertama-Kali-Pada-17-November2019-Di-Hubei-1t11bcmnz73/Full

Mulyadi. (2014). Sistem Akuntansi Edisi 4. In Salemba Empat.

Nugroho, R. E. (2017). Analisis Perhitungan Harga Pokok Produksi Dengan Metode Full Costing Pada Pembuatan Sabun Herbal Di Rpta Kalideres Jakarta Barat. Jurnal Abdi Masyarakat (JAM), Vol 2, No 2 (2017): JAM (Jurnal Abdi Masyarakat)-Maret, $\quad 48-53$. Http://Publikasi.Mercubuana.Ac.Id/I ndex.Php/Jam/Article/View/6101

Nurwani, N., \& Safitri, A. (2019). Pengaruh Penggunaan Informasi Akuntansi Terhadap Keberhasilan Usaha Kecil Menengah (Studi Pada Sentra Dodol Di Kec. Tanjung Pura). Liabilities (Jurnal Pendidikan Akuntansi).

Https://Doi.Org/10.30596/Liabilities. V2i1.3332

PSAK. (2013). Pernyataan Standar Akuntansi Keuangan 1 (Revisi 2009) (Statement Of Financial Accounting Standards). Ikatan Akuntansi Indonesia.

Purnamawati, I. G. A., Yuniarta, G. A., \& Diatmika, I. P. G. (2018). Pelatihan Dan Pendampingan Penyusunan Cost Of Goods Sold Untuk Menentukan Harga Jual Produk Pada Usaha Tenun Di Kecamatan Sidemen Kabupaten Karangasem. International Journal Of Community Service Learning. Https://Doi.Org/10.23887/Ijcsl.V2i1. 13682

SPAP, 2001. (2016). Standar Profesional Akuntan Publik. In Jakarta: Salemba Empat.

Suci, R. (2012). Peningkatan Kinerja Melalui Orientasi Kewirausahaan, Kemampuan Manajemen , Dan Strategi Bisnis (Studi Pada Industri Kecil Menengah Bordir Di Jawa Timur). Jurnal Manajemen Dan Kewirausahaan. 
Sutrisno, D., Suryono, A., \& Said, A. (2016). Perencanaan Strategis Sektor Usaha Mikro Dalam Mengatasi Permasalahan Pemasaran (Studi Di Dinas Koperasi, Usaha Kecil Menengah, Perindustrian Dan Perdagangan Kota Batu). Wacana, Jurnal Sosial Dan Humaniora. Https://Doi.Org/10.21776/Ub.Wacan a.2016.019.02.5

Waryanto, R. B. D., \& Nasrulloh. (2014). Pengaruh Penentuan Harga Pokok Produksi Terhadap Harga Jual Pada Industri Krupuk. Majalah Ekonomi, 109-119.

Wibowo, A., \& Kurniawati, E. P. (2016). Pengaruh Penggunaan Informasi Akuntansi Terhadap Keberhasilan Usaha Kecil Menengah (Studi Pada Sentra Konveksi Di Kecamatan Tingkir Kota Salatiga). Jurnal Ekonomi Dan Bisnis, 18(2), 107. Https://Doi.Org/10.24914/Jeb.V18i2. 269 